\title{
Educational Tourism Movements in and the Danube Region of Fruška Gora - Condition and Development Perspectives
}

Jovan Romelic*

Miladin Kalinic**

\section{Abstract}

Northern slopes of Fruška gora near the Danube area comprise a variety of natural and anthropogenic objects, phenomena and processes. Thus, that area of the mountain has grown into a constituent part of the tourist region of Novi Sad and Fruška gora, which geographical position, structure and quality of tourist attractions and receptive base have contributed to its functionally versatile and comprehensive tourism spatial structure.

A group of professors and associates from the Department of Geography, Tourism and Hotel Management, Novi Sad in cooperation with Tourist Organization of Sremski Karlovci have completed valorisation of this area regarding tourism by application of didactical-methodological approach. They concluded that the Danube basin near Fruška gora might become the location for various educational programmes and trainings, i.e. "lesson in thing" and educational tourism in broader sense.

The paper discusses this hypothesis based upon interdisciplinary scientific and methodological approach to the problem.

Key words: The Danube basin, Fruška gora, school in nature, educational tourism

\section{Research}

Among numerous definitions of educational tourism, we have chosen the one which is both comprehensive and simple and according to which "educational tourism comprises all visits to destinations, out of the tourist's place of residence, primarily motivated by eagerness for education," (Hadžić et al, 2005, 44)

Educational tourism movements in the Danube basin area of Fruška gora demand a divergent approach to the research. Although the subject of the research is the area in Novi Sad Fruška gora tourist region, its subregional position stipulates the prominent investigation of

* Faculty of Science, Department of geography, tourism and hotel management, Novi Sad, www.ig.ns.ac.yu

** Creative Club "Educo", Sremski Karlovci 
attractive resource and receptive base for educational tourism. Moreover, it is necessary to explain actual utilization of the possibilities for this type of tourism.

With regard to tourism needs, many tourists visiting this area are not primarily motivated by the need to participate in educational tourism; however, they take part in it. On the other hand, there are tourists, who joined organized tours to this area, (e.g. school visits, course attendants, students' excursions) or who arrived with their families and in groups, (e.g. one day trips, which are frequently not clearly defined regarding cultural needs) and are motivated by outer or inner factors and with conscious or unconscious desire for education.

\section{The Danube basin area of Fruška gora with locations suitable for educational tourist offer}

The Danube basin area of Fruška gora with its natural, geographical and social objects, including settlements (Sremski Karlovci, Sremska Kamenica, etc.) offers indisputably rich and versatile natural and anthropogenic objects, phenomena and processes. The main hypothesis of the paper is that the Danube basin area of Fruška gora might become the location for various educational programmes and trainings, i.e. "lesson in things" and educational tourism in broader sense, with the regard to didactical and methodical aspect of tourism.

It is important to highlight that most of educational excursions towards this area have been short trips (half day or transit). The length of stay implies a simple information reproduction without offering the possibility for realisation of teaching content and other cognitive processes, which achieve their substantial quality level only through application of obligatory didactical and methodical principles. On the other hand, these locations proudly boast their wealth and variety of objects, phenomena and processes, which provide favourable conditions for necessary stationary stays ( 5 to 6 days). The role of residential educational centre would be assigned to Sremski Karlovci with its locations Stražilovo and Dvorska bašta. Natural and artificial objects in the surroundings would complement educational and non-educational activities.

Utilisation of contemporary findings and practical experience about tourism aspects of the area as well as didactical research, i.e. experience in organisation of educational excursions and field work have been employed to register the objects in natural and artificial environment of the Danube basin area of Fruška gora. Furthermore, the compulsory criteria for an area to meet didactical principles and organisational standards of teaching have been applied to those objects. According to that, the presence of the following facilities may be highlighted:

1. This area offers the possibility for realisation of several types of "lesson in things", which would attract further educational tourism movements, starting from physical, social and geographical components of the area and adjacent didactical principles: students' tourism, youth tourism, excursions, summer educational camps, schools in nature, foreign languages schools, research camps, professional and study stays for adults, etc.

2. Tourism organisations and other significant factors gradually introduce measures for providing receptive, communication, infrastructure, suprastructure and organizational base and marketing activities.

3. Tourism organisations in cooperation with students of pertinent higher education in Novi Sad may examine demand features, by means of distinctiveness analysis and demands of certain consumer categories: preschool and schoolchildren, students and faculties, various organisations, cultural associations and sections, experts and scientists, enthusiasts and admirers of natural and cultural values. 
4. There are several completed specialised itineraries for school and other excursions within which this area would be considered as a short stop, a focal point for daily or weekend breaks or a location for several days long "lesson in things", etc. They enable the visit to significant values depending of the age or other relevant characteristics of groups of visitors, etc.

5. The survey of schools and institutions in educational system should be conducted to examine the role of demand factors for applicable contents and procedures of their application. Thus, an opportunity would be given to initial and receptive travel agencies to create technical and organizational aspect of stays in this area.

6. Perennial and current problems in organisation of educational tourism such as propaganda and information, transport, accommodation, organisation of stays (indoor and outdoor facilities, preserved assets, values that should be transformed in order to adapt to demands of "lesson in things") are being solved.

\section{Possible forms of educational travelling}

The tourist offer based upon utilisation of cultural heritage and its combination with complementary tourism values is possible to be formed in the Danube basin area of Fruška gora, such as the following:

1. Historical tours: travelling aimed at reconstruction of historical events; travelling to important places for different historical periods or organised migrations (e.g. Great migrations in 169o); travelling to perceive certain time periods; travelling to understand history of religion in the area of Vojvodina (visits to monasteries and other religious objects).

2. Cultural and geographical travelling: introduction to cultural and historical attractions of Sremski Karlovci and Novi Sad and presumably other localities in Novi Sad zone; specialised travelling to learn about specific cultural values (monuments, cultural and ambiental units, etc.); cultural travelling with itineraries including the areas where the most important objects of artistic movements are found (e.g. Baroque routes); for customers of higher cultural and educational need the tour of Fruška gora and authentic Vojvodina as depicted in the works of Serbian writers who wrote about historical or contemporary periods (e.g. Vojvodina in books of Mladen Markov and Arsen Diklić, revelation of Novi Sad, Sremski Karlovci in books and life of Branko Radičević, Sremska Kamenica in books and life of Jovan Jovanović Zmaj, Milica Stojadinović Srpkinja and her poetry; this area in books of other writers who presented it in most authentic and suggestive ways)

3. Travelling to seminars: Holding a series of seminars and alternating their venues in cultural institutions of spatially close towns, directly or indirectly connected with the topics of seminars.

4. Monumental tours - visiting the values that need conservation and restoration (Romelić, Tomić, 2003/2004)

\section{Schools in nature in Sremski Karlovci}

Prominent natural, cultural and historical features of the geographical area of Sremski Karlovci and the surroundings as well as the need for attending the school in nature of didactical character with both educational and recreational content were the initial steps for the School 
in nature. Tourism organisation of Sremski Karlovci made efforts and drafted the School programme, with the emphasis on careful and regular monitoring of the results. The observation and verification of students' progress by the end of the five-day stay would become the experience turned into affirmation or correction of the content.

The School's five-day activities for its students are more or less fixed: tour of Sremski Karlovci, tour of the Petrovaradin fortress, cycling competition "Dvorska bašta cup", stay in Eco and ethno park, tour of Novi Sad, tour of Fruška gora monasteries, participation in sports and recreational activities, etc.

\section{Summer school in Sremski Karlovci - CC "Educo"}

Mission of the School Project: Creative club "Educo" within its scope of activities cooperates with diaspora in the field of culture and education.

Aims of the Summer School: to create opportunities for Serbian children in diaspora to make friends with their age groups from Serbia and other countries in the authentic ambience of Sremski Karlovci, to learn the language, customs, culture and tradition of Serbia following a creative curriculum.

The Summer School is organised by Creative club "Educo" because there is the need for facilitating the interest of Serbian people both abroad and at home to preserve their cultural identity. In order to conduct the task comprehensively and achieve high quality level, it is necessary to establish cooperation and contacts between the Serbian diaspora and the Serbs in Serbia to maintain national interests and meet the needs.

It is our hypothesis that Serbian migrants all over the world, who gather in various associations, should be involved in preservation of their cultural and religious identity, language and writing as well as Orthodox Christianity by means of establishing close relationship and cooperation with cultural and educational institutions in Serbia.

The School Project in Sremski Karlovci implies the organisation of a creative stay of children and young adults in their homeland, as well as young people of different nations interested in our cultural heritage. The Project comprises the ten-day courses in Serbian language, customs and culture. Appreciation of active learning and participation in workshops, visiting playgrounds and hands on learning at various locations are among possible forms of culture development. The learning process is conducted not only within the cognition filed, but also includes attitudes, emotion and behaviour. Knowledge acquisition about the ancestry is more interesting, rational and economical. Summer holiday accommodation is provided in Ecological centre and Sokolski dom in Sremski Karlovci. During their stay, the participants attend the educational part of the programme (courses in Serbian, history, ethnology and religion) at cultural and historical heritage locations of Fruška gora and the Danube basin. Within the Programme, special emphasis is given to anniversaries of important people in Serbian culture and history. Thus, the year 2006 was devoted to Nikola Tesla, the man of all times, the year 2007 to Dositej Obradović, who brought the spirit of Europe to Serbia and made the first steps in cultural connections of Serbia with the world.

Afternoon creative programmes foster creative skills of the attendees in music, drama and art, whereas the evening hours are reserved for EDUCO workshops, meetings with celebrities and recreational programmes. Moreover, there are organised trips and tours to Novi Sad, the Petrovaradin fortress, Stražilovo, monasteries of Fruška gora and Belgrade. The trips are useful since the attendees of the Summer School are directly introduced to cultural and histor- 
ical heritage and natural assets of the environment. The School Council establishes the Programme of the Summer School which is realised by the team of professors of the University of Novi Sad, teachers of Karlovačka Gimnazija (Grammar School), teachers of Karlovačka Bogoslovija (Theological faculty), members of MENSA, artistic and drama associations' members and volunteer students.

Project's target groups and beneficiaries are the children (aged 14 to 18 and older) of Serbs living in diaspora, the children of autochthonous Seriban population in neighbouring countries (aged 14 to 18) and the children of similar age groups but different nationality who want to meet our language and culture and customs.

The project is realized during summer holidays, in July and August.

Previous experience has shown that the children participating in the Project mainly arrive from European countries Romania, Hungary, Austria and Germany (towns - Vienna, Timisoara, Budapest and Stutgart).

Furthermore, the participation of attendees from former Yugoslav republics (Republic of Srpska, FYR Macedonia, Slovenia, Croatia), groups and individuals from towns of Banja Luka, Trebinje, Skopje, Kumanovo, Ptuj, Ljubljana, Zagreb, etc. is noticeable.

After the annual completion of the Project, the evaluation is conducted in order to estimate the realisation level of aims and tasks and obtain the basis for maintenance and improvement of successful organisational procedures and correction of procedures which have appeared as inadequate. The evaluation process is conducted by application of the following techniques: observation, survey, interview, documentation analysis (diaries and works of attendees) and tests. The following instruments are used: checklists, protocols for monitoring the survey, questionnaires, conversations, group and individual checklists and non-standard tests. The evaluation is conducted during the Project and after completion by the project realisation team - School Council and Project participants.

The attendees' responses have justified the Project expressing high satisfaction level of acquired knowledge about Serbian culture, language and customs, perceiving similarities and differences with the culture of the country they live in.

The number of attendees who decided to continue education in Serbia after the completion of the Summer School has increased (e.g. Karlovača gimnazija (secondary grammar school), Bogoslovija (Theological faculty) and the University of Novi Sad or Belgrade). Moreover, there have been numerous wedding and baptism ceremonies held in Sremski Karlovci (e.g. attendees from Vienna and Stuttgart), as well as the examples of established permanent communication with the homeland.

Three hundred and eighty (380) attendees from all over the world have attended the Summer School. (Data obtained from CC "Educo").

\section{Conclusion}

The Danube basin area of Fruška gora with regard to its educational tourism purposes comprises several smaller settlements with their surroundings (Novi Sad is not included), as the settlements stand for prominent regional nuclei of tourism valorisation, having attractive resource base for mass and versatile educational tourism to a certain extent. This area has primarily been the spotlight of public discussions, owing to the plans for its permanent quality direction towards this type of tourism. Although the movements in tourism are outward bound and dispersive, they show progressive character as distinct from their weaknesses. On 
the other hand, intended visits are connected with the locations for schools in nature, recognisable cultural assets outside the settlements and the settlements themselves that are functional for tourism purposes. The visits to e.g. Sremski Karlovci are observed as frequent and periodical, organised or spontaneous. Regardless the whole range of deficiencies, educational tourism travelling is gaining the form of institutionally organized education for attendees from distant emissive places. The paper has described two examples, each being a model of an educational event in its own right, which may initiate this form of tourism movements within international contraction zone.

\section{References}

Hadžić, O. et al (2004): Cultural tourism, Department of Geography, Tourism and Hotel Management, Faculty of Science, Novi Sad. (in Serbian)

Romelić, J., Kalinić, M. (2007): The role of events in tourist offer of Sremski Karlovci, Tourism, Contemporary trends in tourism, hotel management and gastronomy, pp 112-114. (in Serbian)

Romelić, J. (2007): Interest grouping intended for creation of integral tourist offer of Sremski Karlovci, Collection of papers, Department of Geography, Tourism and Hotel Management, Faculty of Science, No. 37, Novi Sad., pp 63-75. (in Serbian)

Romelić, J., Tomić, P. (2003/2004): Offer Sremski Karlovci as a potential tourist and educational centre. Department of Geography, Tourism and Hotel Management, Faculty of Science, No. 33/34, Novi Sad, pp 161-172(in Serbian) 